\title{
INTERNET - A NEW ENVIRONMENT FOR LIFE AND EDUCATION (?)
}

\section{[INTERNET - NOVÉ PROSTREDI PRO ZIVOT A UCENI (?)]}

\author{
Jitka Jursova
}

\section{DOI: 10.18355/PG.2015.4.2.259-271}

\begin{abstract}
The aim of this article is to shed some new light on questions of education considering changes in lifestyle of current young generations, for whom ICTs play an increasingly significant role.

The author presents results from questionnaire surveys, which have been conducted continuously since 2002. They expose the necessity of targeted information and media education in order to remedy the activities of children and youth in virtual environment and as such to become an effective tool for the prevention of negative consequences of virtual reality for the personal development of young people.
\end{abstract}

\section{Keywords}

Information education, media education, virtual reality, Internet, cyberspace, Net Generation, e-learning, social networking

\begin{abstract}
Abstrakt
Příspěvek si klade za cíl uvést otázky výchovy a vzdělávání dětí a mladých lidí do souvislosti se změnami v životním stylu mladé generace, v němž stále významnější místo zaujímá intenzivní kontakt $\mathrm{s}$ informačními a komunikačními technologiemi.

Autorka ve svém př́spěvku seznamuje s výsledky výzkumných šetření, prováděných kontinuálně od roku 2002. Na jejich základě poukazuje na nezbytnost cílené informační a mediální výchovy, která pomáhá korigovat aktivity dětí a mládeže ve virtuálním prostředí a stává se účinným článkem prevence negativních důsledků působení virtuální reality na vývoj osobnosti mladého člověka.
\end{abstract}

\section{Klíčová slova}

Informační výchova, mediální výchova, virtuální realita, internet, kyberprostor, Internetová mládež, e-learning, sociální sítě

\section{Úvod}

Současná nejmladší generace vyrůstá v tzv. informační společnosti, jejíž fungování je stále úžeji spjato s počítači a počítačovou sítí a jejíž charakteristikou je potřeba a šíření počítačové gramotnosti. Informační společnost $\mathrm{s}$ sebou přináší nesporná pozitiva $\mathrm{v}$ podobě demokratičnosti $\mathrm{v}$ př́stupu $\mathrm{k}$ informacím a možnostem komunikace i nových cest šíření vzdělání a vzdělanosti. Zároveň však způsobuje neplánovaný efekt, který si 
opětovně uvědomuji pokaždé, když vidím oči dětí vpité do ploché obrazovky: „Člověk se ad absurdum stává př́idavným zařízením počítače, s důsledky pro jeho myšlení, cítění a prožíváni““ (Sak, Sakova, 2004: 201).

ICT a celosvětová komunikační a informační sít' - internet jsou fenoménem, který proniká do všech oblastí života společnosti a kvalitativně ji proměňuje. Životní prostor jednotlivce i celé společnosti se nebývalým způsobem rozšiřuje. Vzniká nový prostor pro socializaci člověka, mění se podmínky jeho života. Explozivní nástup internetu na konci 20. století zároveň otevřel novou éru ve vývoji lidské komunikace.

Internet jako nové komunikační médium přináší ve vývoji komunikace radikální změnu: Jak píše mediální analytik M. Smid (2001: 213-218), internet přesahuje a rozšiřuje pojem masového média, kde jsou přesně vydefinovány charakteristické rysy komunikátora, př́ijemce, sdělení a zpětné vazby. Především již není jen komunikačním prostředkem, ale stává se prímo komunikačním prostředím - tedy prostorem, v němž komunikace probíhá. Navíc umožňuje všechny možnosti komunikace (jednoho k jednomu, jednoho k mnoha, mnohých k mnoha apod., a to jak simultánně, tak i s časovým posuvem) a otevírá tak novou kvalitu média, jehož prostřednictvím neprobíhá pouze masová komunikace (jak je to u ostatních masmédií), ale v naprosté většině jde o komunikaci interpersonální - zprostředkovanou počítačem (tzv. Computer Mediated Communication - CMC).

260 Podle N. Negroponte (2001) je současná éra informatizace společnosti a vznik tzv. infosféry přirozeným pokračováním evoluce. V souladu s vývojem a transformací hmoty v kosmu se v lidské civilizaci mění význam hmotné, energetické a informační interakce ve prospěch interakce informační.

V souvislosti s vývojem digitálních médií nabídl Marshall McLuhan (2000) svou teorii „globální vesnice“ (,global village“), tedy světa, v němž díky moderním technologickým možnostem médií padnou komunikační, a tím i geografické, politické, národní a jiné bariéry, a lidé na celém světě si budou moci svobodně vyměňovat své názory a sdílet všechny dostupné informace. McLuhan předpověděl, že působením médií bude ovlivněno jednání a chování lidí, jejich vzájemné vztahy, zvyklosti a vlastně celé fungování lidské společnosti. Podle této teorie bude širrení informací stále jednodušší a informace se stanou veřejným vlastnictvím. Skutečně můžeme během relativně krátké doby sledovat rozvíjející se možnosti rychlejší a širší komunikace a rychlejšího a snadnějšího přístupu k informacím.

$\mathrm{Na}$ druhé straně již mnohé hlasy varují např. před virtualizací lidských vztahů a dalšími problémy, které může přinést tzv. kyberkultura. Např. Lévy (2000) předpokládá jako důsledek spojení života člověka s kyberprostorem izolaci lidí, stres z kognitivního přetížení, vznik závislostí (na hrách, digitální navigaci, chatování apod.), posilování dominance kontrolních a rozhodovacích center, rozšíření možností vykořistování (např. dozorovanou prací na dálku), zahlcení zbytečnými sděleními, nové formy konformity apod. 
Velmi vážným důsledkem soustavného soužití dětí s ICT je, slovy P. Saka (2004: 124) „radikální proměna sociálního pole mládeže“, proměna struktury trávení volného času a celkového životního stylu mladé generace, zahrnujícího v sobě i způsob poznávání světa, vzdělávání, výchovy a sebevýchovy. Do značné míry mládež vlastně žije ve virtuální realitě utvářené elektronickými médii (tráví v ní množství času, hledá v ní odpovědi na své otázky, baví se, navazuje a udržuje kontakty, získává zkušenosti). P. Sak právě pro tento jev označuje současnou generaci jako „mediální mládež“. V angličtině bychom našli další označení, zdůrazňující těsný vztah dětí s interaktivními médii - Connexity Generation, Net Generation, Generation I., nebo také „Clickerati““.

Trend vývoje směřuje jednoznačně ke zvyšování podílu pobytu a aktivity mladých lidí ve virtuálním prostředí oproti jejich aktivitě v přirozeném časoprostoru a ke koexistenci v prostř̌edí virtuálním a reálném. Škola tak stojí před závažným úkolem - změny v životě společnosti reflektovat a mladou generaci již připravovat pro život $v$ radikálně odlišném světě od toho, v němž vyrůstaly předchozí generace.

Jak ale varuje P. Sak (2004), pozornost společnosti i vlády je př́liš soustředěna na vybavenost informačními a komunikačními technologiemi a počítačovou a informační gramotností. Přitom jsou dosud velmi podceňovány a opomíjeny pedagogické, psychologické a sociologické důsledky ,komputerizace“ společnosti. Důsledky, které se možná projeví až za několik let, mohou být fatální - ovlivnění fyzické kondice, metabolismu, psychického i fyzického zdraví, hodnot, vztahů, citů a jejich projevi̊. Důsledkem soustavné interakce člověka s virtuálním prostředím internetu mohou být neurologické změny v mozku, jak upozorňuje např. $M$. Spitzer (2014).

Je tedy třeba hledat nové cesty výchovy a vzdělávání mladých lidí, které na jedné straně respektují vývojový trend a na straně druhé pomohou mladým lidem orientovat se v novém prostředí, tak odlišném od životního prostředí, v němž vyrůstali jejich prarodiče a rodiče, učit se, pracovat, bavit se a žít kvalitní, plnohodnotný život.

\section{Elektronická média a výchova}

Existence člověka zároveň $\mathrm{v}$ přirozeném i virtuálním světě s sebou nese závažnou skutečnost: Osobnost člověka se utváří interakcí se světem v dynamické rovnováze osobnostní struktury, myšlení, cítění a jednání. Dlouhodobý pobyt v kyberprostoru, tedy umělém prostoru vytvořeném prostřednictvím digitálních technologických prostředků, nabízí k interakci jiný, virtuální svět. V něm neplatí zákonitosti přirozeného světa a mění se tím vnitřní svět člověka, jeho myšlení, cítění i jednání. To má vliv na osobnostní strukturu a tedy na rozvoj osobnosti člověka.

Fenomén, který má pravděpodobně v současnosti nejsilnější vliv na posun životního pole dětí směrem k virtuální realitě, se nazývá sociální sítě. Stejně jako mobilní telefony, i ony překvapily rychlostí svého nástupu a 
rozšíření mezi mladými lidmi. Jde o systémy, fungující v prostředí internetu, které slouží navazování a udržování sociálních vztahů a komunikace. Interentovou sociální sítí, mladou generací v naší zemi nejvíce využívanou, je v současné době bezesporu Facebook.

Facebook je sociální webový systém, sloužící ke komunikaci, navazování a udržování vztahů mezi uživateli a sdílení multimediálních dat. Je typickým virtuálním prostréedím, napodobujícím reálný život. Mladí lidé v něm prožívají neopominutelnou část svého běžného dne, „scházejí se“, baví se, diskutují, domlouvají si akce, sdílejí své zážitky, dojmy, fotografie, hrají hry, spolupracují v různých aktivitách včetně studia a domácích úkolů. Facebook je relativně velmi mladý, široké veřejnosti je otevřený od srpna 2006. Po čtyřech letech, v roce 2010 se již podle statistických údajů mohl pochlubit 500 miliony aktivních uživatelů a fungoval v 65 jazykových modifikacích. V červnu 2015 je přeložen do 84 jazyků a počet aktivních uživatelů dosáhl počtu 1,5 miliardy (Statistika, 2015).

V naší zemi je Facebook mezi mládeží nebývale rozšířen. V současnosti je běžným komunikačním prostředím i pro školáky, dokonce i na 1. stupni ZŠ, přestože v jeho registračních podmínkách je stanovena spodní hranice využívání této sítě věkem 13 let. Dětmi je chápán Facebook jako prostředí pro trávení volného času a zábavu, naskýtá se však zajímavá a v současnosti relevantní otázka potenciálu Facebooku být i prostředím pro vzdělávání, resp. pro komunikaci související s učením.

262 Z pedagogického hlediska můžeme nahlížet na elektronická média a virtuální prostor jimi vytvářený ze dvou úhlů pohledu: jako prostor pro rozvoj jedince, tedy prostor napomáhající výchově, nebo jako rizikový faktor, působící ve vztahu k výchově kontraproduktivně.

Např. jedním z problémů, které internet přináší a které již velmi silně pocit’ujeme, je zahlcení informacemi - tzv. informační smog (Sak, 2004). Obsah sdělení, která se prŕjemcům dostávají, představuje široké spektrum od zásadních vědeckých poznatků a životně důležitých informací přes nepotřebná sdělení, banality, nevyžádané reklamy až po primitivní, vulgární a agresivní výplody cizí mysli, které zbytečně zahlcují prostor a mozkové kapacity každého z nás.

Jiným závažným problémem je nebezpečí přenášení prožitků a zkušeností mezi virtuálním prostř́edím a přirozeným světem (např. prožitky a zkušenosti z bojových počítačových her, z virtuálního zabíjení atd.) virtuální „normalita“ mění vnímání normality v přirozeném světě a může vážně narušovat výchovu a rozvoj osobnosti mladistvých. Ve výčtu potíží spojených s působením internetu na mladou generaci bychom mohli pokračovat: od nevhodných webových stránek, které mohou negativně ovlivňovat výchovu dítěte, přes nebezpečí navázání kontaktu s nebezpečnými lidmi, ztrátu anonymity a soukromí, až po zdravotní potíže, poruchy nervové soustavy a poškození mozku jako důsledky zatížení organismu dítěte dlouhodobým pobytem ve virtuálním prostředí. 
$\mathrm{Na}$ druhou stranu internet přináší nové možnosti vzdělávání: e-learning, virtuální knihovny, konference, přednášky, interaktivní encyklopedie (nejen Wikipedii) a jiné bohaté zdroje poznání, společné studium prostřednictvím sociálních sítí, e-twinning a jiné možnosti společných vzdělávacích projektů v celostátním i mezinárodním měřítku apod. Počítač a internet je možné úspěšně používat k cílenému podněcování samostatného sebevzdělávání žáků, $\mathrm{k}$ individualizaci výuky např. prostřednictvím vhodně volených domácích úkolů, $\mathrm{k}$ usnadnění kontaktu učitele se žáky i žáků vzájemně mimo dobu vyučování. Počítače mají potenciál obohatit vzdělávání zdravotně postižených či dlouhodobě nemocných dětí, nebo naopak talentovaných žáků ve škole i mimo ni.

V poslední době se stále častěji internet uplatňuje jako prostor pro spolupráci školy a rodičů, veřejnosti. Téměř všechny školy se již prezentují vlastními internetovými stránkami, elektronickými školními časopisy, mnohé školy zřídily on-line informace pro rodiče o docházce a výsledcích učení jejich dětí. Některé školy již dnes dokonce ruší papírové podoby žákovských knížek.

Virtuální prostředí se tedy může stát novým sociálním i výukovým prostorem, počítače zaujímají místo novodobých didaktických prostředků.

Na začátku 90. let byly do počítačů ve výuce vkládány velké naděje. Např. psycholog L. Vajner (1993) píše o práci s počítačem jako o činnosti, kterou se rozvíjí celá osobnost člověka: vědomosti, fantazie a tvořivost, odpovědnost, numerická a prostorová představivost, rychlost reagování apod. Aktivní práce s počítačem údajně zlepšuje schopnost řešit problémy, posiluje vůli, sebehodnocení, zvyšuje aktivitu a motivaci k učení.

Mnozí odborníci však varují, že přehnané využívání počítače ve výuce, zvláště mladších dětí může vést až ke snížení schopnosti tvořit pojmy a k omezení představivosti (Larsen, 1988: 28-38). Při interakci mezi dítětem a PC je totiž do jisté míry omezena možnost praktických manipulací, hmatových a motorických vjemů. Některé výzkumy vedly k závěrům ${ }^{1}$, že při počítačové výuce se děti učí rychleji, ale tradičními metodami uchovají více a déle v paměti (Larsen, 1988: 28-38).

M. Spitzer (2014) důrazně varuje před nadužíváním ICT v procesu vyučování žáků, zvláště na nižších stupních škol - s odkazy na mnohé výzkumy v oblasti neurobiologie, které prokazují, že kontakt s digitálními médii negativně ovlivňuje pozornost, schopnost se soustředit, pamět' a další psychické procesy.

Očekávání spojená s ICT nebývají často ve školách z různých důvodů naplněna. D. Clark (2007) v této souvislosti píše o mnoha mýtech spojených $\mathrm{s}$ výukou prostřednictvím $\mathrm{PC}$ a internetu - např. o přeceňování

${ }^{1}$ např. výzkumy Splitbergera v r. 1979, Kulika, Bangerta a Williamse v r. 1983, jež zmiňuje Larsen, (1988)

Slavonic Pedagogical Studies Journal Vol. 4 Issue 2, September 2015 
hyperučení (s využitím multimédií), přičemž tradiční metody práce mohou mít $v$ některých př́padech i lepší výsledky, o domněnkách, že se elektronické učení dokáže přizpůsobit individuálnímu učebnímu stylu studenta, jenomže ne každý e-learningový program to skutečně umí, o přecenění aktivizace žáka, zatímco ve skutečnosti i u počítače může být žák pasivní, apod.

S J. Marešem (2007: 177-179) můžeme konstatovat, že stejně jako každá technická novinka ještě nemusí být výrazným pokrokem v kvalitě učení, tak i e-learning a jakékoli učení prostřednictvím počítače nemusí být nutně lepší než tradiční vyučování. Elektronické učení také vnáší do pedagogiky nové otázky, problémy (např. na jedné straně vysoké nároky na učitele př̀i př́pravě výukového programu, na straně druhé pak snahy žáků zjednodušit si práci, obelstít systém, nový fenomén - elektronické podvádění (cybercheating, e-cheating), kybernetické plagiátorství apod.).

$\mathrm{V}$ současnosti je třeba kromě řešení otázek zajištění dostupnosti technologií ve vzdělávacím procesu a kvalitního vzdělávání učitelů $\mathrm{v}$ této oblasti s důrazem na didaktické otázky využívání moderních technických prostředků ve výuce soustředit pozornost také na zkoumání efektivity a pozitivních i negativních vlivů ICT na procesy učení. Je nezodpovědné a poněkud pošetilé posuzovat „,modernost" a kvalitu školy podle toho, zda je vybavena interaktivními tabulemi a v poslední době tablety, dokud nebyly seriózními výzkumy potvrzeny znatelné pozitivní efekty takto vedené výuky.

\section{Internet $\mathbf{v}$ životě mladé generace - výzkumné šetření}

\subsection{Cíl výzkumu, výzkumné problémy}

Provedený výzkum byl směřován $\mathrm{k}$ ověřování podílu prostředí internetu na výchově a vzdělávání mladé generace.

Výzkumné problémy se týkají

- podílu internetu na informální výchově

- způsobů využívání internetu žáků a studentů v souvislosti se sebevzděláváním a seberozvojem

- participace školy na podpoře sebevzdělávacích aktivit žáků a na rozvíjení dovedností k efektivnímu využívání internetu pro vlastní rozvoj

\subsection{Charakteristika metod výzkumu a souboru respondentů}

Otázky využívání internetu mladou generací a jeho výchovných a vzdělávacích možností byly součástí rozsáhlého výzkumu zaměřeného na vztah masově komunikačních médií a výchovy, prováděného v letech 20022010. Pro účely tohoto př́spěvku byly využity výsledky následujících dílčích šetření:

1 „Sebevzdělávání ve volném čase“, realizované prostřednictvím nestandardizovaného dotazníku pro žáky 5.-9. trríd ZŠ v roce 2002 na třech školách s výrazně odlišnými podmínkami: ZŠ v obci (112 žáků), ZŠ ve městě se 100000 obyvateli (72 žáků) a ZŠ s počítačovým zaměřením (111 žáků). 
2 ,Zdroje informací a jejich využívání“ v roce 2004, výzkum proběhl za spolupráce se studenty, kteří vedli individuální řízený rozhovor se žáky základní školy na základě prripraveného dotazníku. Studenti byli předem vybaveni instrukcemi pro vedení tohoto rozhovoru. Odpovědi žáků zaznamenávali do dotazníku. Bylo zpracováno celkem 261 dotazníků od žáků 6. - 9. ročníku základních škol z různých míst ČR.

3 Dotazníkové šetření „Televize a počítač“ probíhalo formou řízených rozhovorů a dotazníku v jarních měsících 2006, zúčastnilo se jej 90 žáků 6.9. ročníkủ základních škol z celé ČR.

4 „Využití školní knihovny a počítačové učebny“, v roce 2005, z něhož se ke zpracování vrátilo 73 využitelných dotazníků. Respondenty byli žáci 6.-9. tříd ZŠ.

5 „Média ve vzdělávání“ 2007 , nestandardizované dotazníky vyplnilo 467 žáků 2. st. ZŠ.

6 „Mediální výchova“ 2008, dotazník, sémantický diferenciál, 189 žáků 2.st. ZS̆.

7 Průzkum „Sociální sítě“, 2010, dotazníky vyplnilo 92 studentů VŠ a 54 studentů SŠ.

8 Dotazníkové šetření „Učení $\mathbf{v}$ prostředí internetu“ probíhalo formou řízených rozhovorů a dotazníku v dubnu - květnu 2015, zúčastnilo se jej 120 žáků 6.-9. ročníků základních škol a odpovídajících ročníků osmiletých gymnázií v Libereckém kraji.

Reliabilita jednotlivých položek $\mathrm{v}$ dotaznících byla ověřována metodou půlení s výpočtem Cohenova koeficientu kappa.

Statistická významnost rozdílů dvojic porovnávaných skupin při komparaci vybraných výsledků byla ověřována pomocí Studentova t-testu.

\subsection{Výsledky výzkumu a jejich interpretace \\ Dostupnost počítače}

Dostupnost počítačů pro děti školního věku v ČR na začátku tisíciletí velmi rychle narůstala. Podle odpovědí žáků v našem šetření v roce 2003 mělo doma dostupný počítač $60 \%$ dotazovaných dětí (přičemž byly rozdíly mezi dětmi z města nebo venkova - na venkově to bylo cca $52 \%$, zatímco ve městě $70 \%$ ), a v roce 2006 mělo počítač doma téměř $90 \%$ dotazovaných (přičemž už mělo $22 \%$ dětí svůj vlastní počítač) a $71 \%$ dotazovaných domácností bylo připojeno na internet.

V roce 2007 mělo již $80 \%$ dotazovaných dětí internet doma, 23\% dotazovaných dětí má svůj vlastní počítač a pouze $6 \%$ dětí vypovědělo, že počítač doma nemají. V roce 2007 byly již díky zlevnění počítačové techniky a dostupnosti internetové sítě prakticky smazány rozdíly ve vybavení počítačem mezi dětmi městskými a venkovskými.

V roce 2015 uvedlo 54\% dotazovaných dětí v Libereckém kraji vlastní počítač, celkově aspoň jeden dostupný počítač $\mathrm{v}$ domácnosti uvedlo $\mathrm{v}$ tomto šetření $95 \%$ dotazovaných, přičemž všichni, kdo uvedli PC doma, potvrdili zároveň připojení na internet.

Novým fenoménem vedoucím $\mathrm{k}$ ještě těsnějšímu sepětí člověka s virtuálním prostředím internetu, jsou tzv. chytré telefony a tablety, které 
umožňují snadný přístup k internetu kdekoli a kdykoli. Moderní děti jsou prakticky soustavně on-line.

\section{Čas u počítače}

Pro další uvažování o využití PC v rámci vzdělávání a sebevzdělávání žáků jsou důležité údaje o tom, kolik času děti u počítače tráví. V dotazníku v r. 2006 vyplňovali žáci tabulku, v níž zapisovali po dobu jednoho týdne každý den dobu strávenou u počítače.

Šetřením bylo zjištěno, že žáci 2 . stupně ZŠ tráví u počítače v průměru 1 hod. 27 min. denně, jsou však velké rozdíly v užívání počítače mezi pohlavími - dívky 5.-7. třídy stráví u počítače v průměru 1 hodinu 15 minut denně, v 8.-9. ročníku se průměrný čas strávený u počítače snižuje na 50 minut denně. Chlapci tráví u počítače v průměru více času než dívky, v 5.7. ročníku je to $\mathrm{s} 1$ hodinou 45 minutami oproti dívkám ještě poměrně malý rozdíl, k výrazné změně dochází ve vyšších ročnících, kde dívky tráví u počítače času méně, zatímco hoši výrazně více $-\mathrm{v}$ průměru denně 2 hodiny 45 minut.

Prodlužování doby strávené v prostředí internetu je podporováno rozvojem dalších technických prostředků - v současnosti zejména smartphony a tablety.

\section{Činnosti na PC}

V roce 2007 jsme položili dětem otázku, jaké činnosti na počítači vykonávají a jak často. Odpovědi byly zaznamenávány do pětistupňové škály. Z označených odpovědí vyplynulo, že nejčastějšími činnostmi je pro dívky komunikace s jinými účastníky, surfování a vyhledávání informací, pro chlapce hraní her, surfování a vyhledávání informací.

U dívek s přibývajícím věkem ubývá hraní her (5. tř. $29 \%$ denně, 8. tř. denně jen $10 \%$, 9. tř. $2 \%$ denně) a naopak rapidně narůstá surfování a dopisování (surfování 5.-8. tř. kolem 30\% denně, 9. třída denně $67 \%$, dopisování 5. tř. $14 \%, 6 .-7$. cca $30 \%, 8$ tř. $40 \%, 9$. tř. $67 \%$ denně). U hochů se charakter činností s přibývajícím věkem téměř nemění.

V roce 2015 jsme zaznamenali posun ve skladbě obvyklých činností na PC. Na první pohled je složení nejčastějších činností u dívek téměř stejné (komunikace, surfování a vyhledávání informací), avšak rapidně se mění forma komunikace - 43\% dotazovaných dívek nyní tráví denně část svého volného času na Facebooku, dalších 14\% využívá denně jiné formy komunikace prostřednictvím internetu, než Facebook (dopisování, chatování). Dalšími velmi častými činnostmi dívek jsou sledování filmů a videí (uvedlo 30\% dívek) a jako nový fenomén nakupování (22\% dotazovaných dívek uvedlo tuto činnost v otevřené odpovědi).

U chlapců stále vítězí mezi činnostmi na PC hraní her - denně se touto činností zabývá 56\% dotazovaných hochů. Oproti dívkám chlapci dvojnásobně více vyhledávají na internetu informace, které je zajímají (denně 44\%). Denními účastníky komunikace na Facebooku je 40\% hochů, dalších $20 \%$ využívá denně jiné formy komunikace. 
Méně využívají děti počítač jako pracovní či studijní nástroj. Vliv školy na práci žáků s počítačem doma je sice znatelný, avšak více se začíná projevovat až v posledních letech.

Vývojové tendence v obvyklých činnostech žáků ZŠ na PC znázorňuje následující tabulka (tab. 1). Zásadní změnu v aktivitách na počítači přináší Facebook - statisticky významně ovlivnil využívání jiných forem komunikace, u dívek se směrem k němu posunuly i další aktivity (hraní her, vyhledávání informací).

Tab.1 Činnosti na PC (index frekvence aktivity)

\begin{tabular}{|l|l|l|l|l|l|}
\hline dívky & $\mathbf{2 0 0 7}$ & $\mathbf{2 0 1 5}$ & hoši & $\mathbf{2 0 0 7}$ & $\mathbf{2 0 1 5}$ \\
\hline surfuji & 3,27 & 2,61 & surfuji & 3,31 & 2,92 \\
\hline $\begin{array}{l}\text { hledám } \\
\text { informace }\end{array}$ & 3,02 & $\mathbf{2 , 3 0}$ & hledám informace & 2,97 & 2,88 \\
\hline $\begin{array}{l}\text { dopisuji si, } \\
\text { chatuji }\end{array}$ & 3,12 & $\mathbf{1 , 9 6}$ & dopisuji si, chatuji & 2,90 & $\mathbf{2 , 0 8}$ \\
\hline Facebook & - & $\mathbf{2 , 1 7}$ & Facebook & - & $\mathbf{2 , 1 2}$ \\
\hline hraji hry & 2,05 & $\mathbf{1 , 5 7}$ & hraji hry & 3,52 & 3,12 \\
\hline $\begin{array}{l}\text { zpracovávám } \\
\text { úkol }\end{array}$ & 1,74 & 1,65 & zpracovávám úkol & 1,64 & 1,84 \\
\hline
\end{tabular}

Pozn. Odpovédi byly zaznamenávány do pětistupñové škály. Z označených odpovědi byl vypočítán index frekvence činností jako

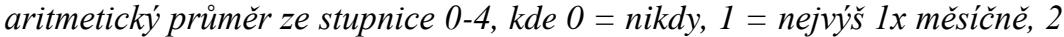

= víc než $1 x$ měsíčně, $3=$ aspoñ $1 x$ týdně, $4=$ denně

V současné době může být vzhledem k vybavení domácností počítač pro většinu žáků nástrojem pro učení a vypracování domácích úkolů. Přesto učitelé nemohou zpracování domácích úkolů na počítačích požadovat vzhledem k určitému procentu žáků, jimž socio-ekonomické podmínky rodiny vybavení počítačem s připojením $\mathrm{k}$ internetu neumožňují. Určitou kompenzací $v$ těchto př́ípadech může být (a v mnoha školách skutečně je) nabídka přístupu $\mathrm{k}$ počítačové technice $\mathrm{v}$ čase mimo vyučování v počítačových učebnách a školních knihovnách. Přístup k počítačům nabízejí také veřejné knihovny.

\section{Využití PC ve škole}

Samostatnou studijní činnost na počítači mimo školní vyučování nelze ve velké míře očekávat, aniž by byla podněcována výchovným působením školy. V našem výzkumném šetření, které jsme opakovaně provedli v letech 2004 a 2006 nás zajímalo, zda škola vychovává žáky k efektivnímu využívání počítačů a internetu zařazováním odpovídajících činností do výuky. Bylo zjištěno, že počítače a internet se prozatím ve vyučování využívaly velmi málo, ještě v roce 2006 se v mnoha školách omezovaly výhradně na výuku informatiky, která však v té době ještě nebyla důsledně a koordinovaně zařazena do učebních plánů všech škol. 
Pokud je práce s počítačem zařazena do výuky mimo předmět informatiku, jedná se ve většině př́padů o procvičování učiva s využitím počítačových výukových programů.

V některých vyučovacích předmětech je podle odpovědí žáků počítač $\mathrm{s}$ internetem využíván k vyhledání informací.

V dotaznících uváděli respondenti dále společnou činnost (ve skupinách, zpracování projektů apod.) a v malé míře vytváření tabulek, grafư a psaní textů.

Počítače jsou využívány nejčastěji při výuce cizích jazyků, dále matematiky, českého jazyka a literatury a zeměpisu, zřjejmě v souvislosti s dostupností odpovídajícího software (zpočátku byly školám dostupné výukové (procvičovací) programy pro počítače právě pro jazyky, matematiku a př́rodovědné předměty).

Třetina žáků (32\%) se ještě v roce 2006 s využíváním počítačů ve výuce (ke studijním účelům) dle svých výpovědí nesetkávala.

K pozitivnímu posunu ve využívání $\mathrm{PC}$ ve výuce dochází ve výrazné míre teprve v nedávné době.

\section{Sociální sítě}

V průzkumu v květnu 2010 [21], jehož se zúčastnilo 92 studentů VŠ a 54 studentů SŠ, odpovědělo $96 \%$ vysokoškoláků a $94 \%$ středoškoláků, že jsou zapojení v sociálních sítích. Z nich $95 \%$ využívá právě Facebooku. 82\% dotazovaných VŠ studentů a $67 \%$ SS studentů vstupuje na tyto stránky denně. Třemi hlavními důvody, proč se studenti na Facebook připojují, jsou komunikace s práteli (jako hlavní aktivita), možnost seznámit se v tomto prostředí s novými lidmi a možnost komunikovat, spolupracovat a hledat informace při domácí přípravě na vyučování.

Z výpovědí respondentů vyplývá, že si většina $\mathrm{z}$ nich $(82 \%$ VŠ a $74 \% \mathrm{SS}$ studentů) je vědoma jistých rizik, která se k využívání sociálních sítí váží. Přesto cca $17 \%$ studentů dle své výpovědi nijak neomezuje informace, které na Facebooku uvádí o sobě a svém životě, včetně rodiny, dalších $65 \%$ sice do určité míry omezuje př́istup $\mathrm{k}$ informacím, které zveřejňuje a dle svého vyjádření uvádí jen ,základní údaje“, ale běžně se zapojuje do diskusí a otevřeně komunikuje. Facebook umožňuje snadné vkládání a sdílení fotografií - polovina studentů v dotazníku uvedla, že na Facebook vkládá veškeré své fotografie, protože je chtějí sdílet s ostatními. Z rizik, která si studenti uvědomují, jmenovali nejčastěji množství času, který v sociálních sítích tráví, a obavy ze ztráty soukromí. Uvědomují si, že i přes zabezpečení citlivých údajů, které sít' umožňuje, je jejich činnost v sociální síti otevíráním soukromí, které může být i nebezpečné. Cca $10 \%$ studentů napsalo, že pobyt v sociální síti je vlastně pobytem ve virtuálním, nereálném světě, který je vzdaluje životu reálnému. Někteří výslovně přiznávali, že stále tráví čas v internetovém prostředí, přestože si jsou vědomi, že jim pak zbývá méně času na učení, sportování a zájmové činnosti. 


\section{Internet jako zdroj informací}

Zajímavým zjištěním tohoto výzkumu byly preference žáků $\mathrm{k}$ internetu oproti jiným zdrojům informací a především skutečnost, že možnost vyhledávat informace na internetu nemusí ovlivňovat negativně práci s ostatními zdroji informací. Naopak - žáci ze zkoumaného vzorku, kteří jsou zvyklí pracovat s internetem jako zdrojem informací, vyhledávají informace i v jiných zdrojích častěji, než žáci, kteří s internetem jako zdrojem informací tak často nepracují. Lze se tedy domnívat, že problém malého využívání odborné literatury žáky a studenty, které pedagogy trápí, není v možnostech, jež přináší internet, jak by se mohlo na první pohled zdát, ale spíše v celkovém návyku a potřebě dítěte vyhledávat informace a získávat poznatky.

Internet je žáky 2. stupně ZŠ považován za nejpřínosnější z dostupných masově komunikačních médií. Dokládá to výzkum z r. 2008, v němž žáci ve škálách zaznamenávali své názory na jednotlivá média. Internet vítězil nebo se umist'oval na předních místech mezi pěti nejběžnějšími médii (televize, knihy, tisk, rádio) v mnoha parametrech, napr.:

- $\quad$ srovnatelně s knihami je považován za nejlepší prostředek vzdělávání

- $\quad$ jako médium umožňující odpočinek se umístil těsně za televizí

- $\quad$ nejvíce ze všech médií je chápán jako prostředek dobrého využití volného času

- $\quad$ výrazně před ostatními médii se v názorech žáků umístil jako nejlepší prostředek k vyhledávání informací

- $\quad$ žádné jiné médium nedostalo tolik hlasů jako internet u tvrzení „bez tohoto média se neobejdu“.

Přehled vybraných položek uvádí následující tabulka, v níž jsou zároveň v posledním sloupci zobrazeny odpovědi žáků ZŠ na stejné otázky, týkající se internetu v roce 2015. I dnes zůstává internet médiem vnímaným jako př́nosné, s poměrně vysokým potenciálem vzdělávat. Kritičtěji již dotazovaní žáci nahlíželi v letošním roce na internet jako na způsob dobrého využití volného času navzdory množství času, který v prostředí internetu skutečně tráví.

Tab. 2 - Názory na média

\begin{tabular}{|l|r|r|r|r|}
\hline & $\begin{array}{l}\text { televize } \\
(2008)\end{array}$ & $\begin{array}{l}\text { knihy } \\
(2008)\end{array}$ & $\begin{array}{l}\text { internet } \\
(2008)\end{array}$ & \multicolumn{2}{l|}{$\begin{array}{l}\text { internet } \\
(\mathbf{2 0 1 5})\end{array}$} \\
\hline Jsou př́nosné & 1,63 & 1,55 & $\mathbf{2 , 4 2}$ & $\mathbf{2 , 2 7}$ \\
\hline Vzdělávají & 0,71 & $\mathbf{2 , 2 9}$ & 2,03 & 1,73 \\
\hline Odpočinkové & 2,03 & 1,53 & 2,03 & 1,48 \\
\hline Vyžadují hodně úsilí & $-1,47$ & $-0,87$ & $-1,50$ & $\mathbf{- 1 , 9 3}$ \\
\hline $\begin{array}{l}\text { Mají moc ovlivňovat } \\
\text { myšlení lidí }\end{array}$ & 1,08 & $-0,11$ & 0,68 & 0,66 \\
\hline Žrout času & & & & $\mathbf{1 , 0 0}$ \\
\hline
\end{tabular}




\begin{tabular}{|l|r|r|r|r|}
\hline Inspirují & 0,45 & 1,32 & 1,03 & $\mathbf{0 , 2 7}$ \\
\hline $\begin{array}{l}\text { Dávají mi vzory, jak } \\
\text { jednat }\end{array}$ & $-0,41$ & 0,21 & $-0,76$ & $-0,30$ \\
\hline Neobejdu se bez nich & $-0,13$ & $-0,32$ & 0,53 & 0,05 \\
\hline Rozvíjí myšlení & $-0,32$ & $\mathbf{1 , 6 1}$ & 0,50 & 0,66 \\
\hline $\begin{array}{l}\text { Dobré využití volného } \\
\text { času }\end{array}$ & $-0,18$ & 0,87 & 0,82 & $\mathbf{0 , 0 0}$ \\
\hline
\end{tabular}

Pozn. Odpovědi zaznamenávali žáci v sedmistupňové škále od -3 do 3 jako míru souhlasu či nesouhlasu s jednotlivými výroky

(-3 naprosto nesouhlasím, 3 naprosto souhlasím, 0 neutrální). Údaje v tabulce jsou aritmetickými průměry záznamů v̌̌ech žáků.

\section{Závěr}

Dítě, které nevlastní počítač, chytrý telefon, tablet, je oproti svým vrstevníkům v nevýhodě, kterou školní děti dosti citelně vnímají. Počítač je dětmi přijímán jako prostředek využívání volného času, jako zdroj informací, a především je pro mladou generaci nepostradatelným médiem pro nové způsoby komunikace.

Počítače se staly samozřejmým vybavením škol, mění formy a metody výuky, v mnoha školách pod vedením tvořivých a schopných učitelů žáci prostřednictvím internetu korespondují se spřátelenými školami v zahraničí, vytvářejí vlastní internetové stránky, podílejí se na mezinárodních projektech. Vývoj pokračuje dál, mnohá škola se nyní vybavuje tablety a učitelé se školí v didaktických otázkách využívání moderních technologií.

Je však třeba nepodléhat nekritickému nadšení, ověřovat skutečné efekty využívání nových technologií ve výuce a zodpovědně zkoumat také dopady působení elektronických médií a virtuální reality na dětskou psychiku. Není to jednoduché a i přes mnoho prokazatelných výsledků již provedených vědeckých výzkumů nejsou názory psychologů a pedagogů na míru nebezpečí, která v sobě média a mediální obsahy nesou, jednotné. Svou úlohu totiž kromě technických možností médií sehrávají další faktory, od vrozených dispozic dítěte až po vlivy rodiny, komunity, vzdělávacích institucí, celé společnosti, určující životní styl a vytvářející hodnotový systém mladého člověka. Dopad působení internetu a virtuální reality na psychiku, na strukturu osobnosti, na prožívání a chování se navíc může projevovat až s velkým časovým odstupem.

Vezmeme-li tedy v úvahu výše zmíněné možnosti efektivního využívání ICT ve vzdělávání a celkovém rozvoji mladé generace, na druhé straně možné důsledky negativního vlivu ICT, a také nároky na změny pojetí a organizace výuky, musíme konstatovat, že před pedagogy stojí v souvislosti s rozvojem ICT a jejich implementací do školní práce náročné úkoly: nestačí jen modernizovat výuku a zajistit vybavení populace počítačovou a informační gramotností, ale především hledat cesty k zajištění zdravého vývoje mladé generace ve zcela změněném světě, učit žít s dalším, v tuto chvíli nejmocnějším médiem. 


\section{Bibliography}

CLARK, D. 2007. The Myths and Realities of E-Learning. [cit. 2009-0608]. Available:http://nwlink.com/ donclark/hrd/elearning/myths.html

LARSEN, S. 1988. Nova technika a vychova deti. Detska literatura a nova media. Referaty a diskusni prispevky na 21. kongresu IBBY v Oslo, Norsko 1988. Cesky preklad oficialniho sborniku kongresu Children's literature and the new media. Prague: Spolecnost pratel knihy pro mladez.

LEVY, P. - KASPAR, M. - PRAVDOVA, A. 2000. Kyberkultura. Prague: Karolinum. ISBN 80-246-0109-5.

MARES, J. 2007. Elektronicke uceni a zvlastnosti cloveka. Sak, P. et al.: Clovek a vzdelani vinformacni spolecnosti: vzdelavani a zivot v komputerizovanem svete. Prague: Portal. ISBN 978-80-7367-230-0.

McLUHAN, H. M. - PRIBYLOVA, I. - KREJZA, M. 2000. Clovek, media a elektronicka kultura: vyber z dila. Brno: Jota. ISBN 80-7217-128-3.

NEGROPONTE, N. - KOUBSKY, P. 2001. Digitalni svet. Prague: Management Press: Softwarove noviny. ISBN 80-7261-046-5.

SAK, P. - SAKOVA, K. 2004. Mladez na krizovatce. Prague: Svoboda Servis. ISBN 80-86320-33-2.

SPITZER, M. - RYCL, F. 2014. Digitalni demence: jak pripravujeme sami sebe a nase deti o rozum. Brno: Host. ISBN 978-80-7294-872-7.

SPOUSTA, V. 2004. Masmedia jako socialne-pedagogicky problem. Pedagogicka revue, vol. 56, n. 3, p. 278.

Statistika. 2015. [cit. 2015-09-08]. Available online: http://newsroom.fb.com/company-info.

SMID, M. 2001. Digitalizace medii v historii a soucasnosti. Kabele, J. -

Mlcoch, L. (eds.). Institucionalizace (ne)odpovednosti: globalni svet, evropska integrace a ceske zajmy. Sbornik konference z 1.-2. 12. 2000. Prague: Karolinum, pp. 213-218. ISBN 80-246-0378-0.

VAJNER, L. 1993. Kdy pocitac pod stromeckem? Děti a my, vol. 23, n. 6, pp. 11. ISSN 0323-1879.

PaedDr. Jitka Jursová, Ph.D.

Technical University in Liberec

Pedagogical faculty

Department of pedagogy and psychology

Studentská 2, 46317 Liberec 1

Czech Republic

jitka.jursova@tul.cz 